\title{
Periode Hidup dan Potensi Reproduksi Lalat Tentara Hitam (Hermetia illucens) Linnaeus (Diptera: Stratyomyidae) pada Substrat Kulit Pisang
}

\author{
Fahri Rijal Giffari' ${ }^{1}$, Agus Susanto ${ }^{2}$, Ramadhani Eka Putra ${ }^{1)}$, dan Agus Dana Permana*1) \\ 1)Sekolah Ilmu dan Teknologi Hayati Institut Teknologi Bandung \\ Jl. Ganesha No. 10 Bandung 40132 Jawa Barat Indonesia. \\ 2)Departemen HPT, Fakultas Pertanian, Universitas Padjadjaran \\ J1. Raya Bandung-Sumedang KM 21 Jatinangor Jawa Barat Indonesia. \\ Alamat Korespondensi: agus@sith.itb.ac.id
}

\begin{tabular}{|c|c|}
\hline INFO ARTIKEL & ABSTRACT/ABSTRAK \\
\hline Diterima: $\quad 10-06-2021$ & \\
\hline $\begin{array}{l}\text { Direvisi: } \quad 06-08-2021 \\
\text { Dipublikasi: } 11-08-2021\end{array}$ & $\begin{array}{l}\text { Life Period and Reproductive Potential of the Black Soldier Fly (Hermetia } \\
\text { illucens) Linnaeus (Diptera: Stratyomyidae) on Banana Peels Substrate }\end{array}$ \\
\hline
\end{tabular}

Keywords:

Bio-converter,

Two-sex life table

Kata Kunci:

Biokonverter,

Tabel hidup dua-

jenis kelamin
The black soldier fly (BSF) Hermetia illucens (Diptera: Stratiomyidae) has been widely used as a bio converter agent. H. illucens can be used as poultry and fish feed, because it has a high protein content. The purpose of this study was to determine the reproductive potential of BSF grown on banana peel media based on life-table analysis. Research carried out under laboratory conditions at temperature range of $18-28^{\circ} \mathrm{C}, 55-90 \%$ relative humidity, and a lighting period of 12:12 hours light:dark. Data on mortality and longevity of each stadia, sex ratio, and fecundity were analyzed based on age-stage two-sex life table. The results showed that intrinsic rate of increase $(r)$ were 0.073 and 0.106 per day, finite rate $(\lambda)$ were 1.080 and 1.112 per day, net reproduction rate $(R o)$ were 52.57 and 118.40 offsprings, and mean generation time $(T)$ were 50.85 and 44.75 days, respectively on banana peel and chicken feed as control. The results showed that $H$. illucens fed with chickens feed had the reproductive parameters reproductive parameters better than banana peels. However, this study showed that BSF can be used as bio-converter of banana peels waste.

Lalat tentara hitam atau black soldier fly (BSF), Hermetia illucens (Diptera: Stratiomyidae) telah banyak dimanfaatkan sebagai agen biokonversi berbagai limbah organik. H. illucens telah banyak dimanfaatkan sebagai pakan hewan ternak unggas dan ikan, karena memiliki kandungan protein yang tinggi. Tujuan penelitian ini adalah untuk mengetahui potensi reproduksi BSF yang diberi pakan limbah kulit pisang. Penelitian dilakukan di laboratorium pada kisaran suhu $18-28^{\circ} \mathrm{C}$, kelembaban relatif $55-90 \%$, dan periode waktu pencahayaan 12:12 jam terang:gelap. Larva BSF diberi pakan limbah kulit pisang dan pakan ayam komersil sebagai kontrol. Data mortalitas dan periode hidup setiap stadia, rasio kelamin, dan fekunditas dianalisis berdasarkan perhitungan tabel hidup. Hasil penelitian menunjukkan bahwa laju pertambahan intrinsik $(r)$ adalah 0,073 dan 0,106 per hari, laju kenaikan terbatas $(\lambda)$ adalah 1,080 dan 1,112 per hari, laju reproduksi bersih $(R o)$ adalah 52,57 dan 118,40 keturunan, serta waktu generasi rata-rata $(T)$ adalah 50,85 dan 44,75 hari, masing-masing pada limbah kulit pisang dan pakan ayam. Hasil penelitian menunjukkan bahwa $H$. illucens yang diberi pakan ayam memiliki parameter reproduksi yang lebih baik daripada limbah kulit pisang. Walaupun demikian, penelitian ini menunjukkan bahwa BSF dapat digunakan sebagai biokonverter limbah kulit pisang. 


\section{PENDAHULUAN}

Kulit pisang merupakan limbah organik yang sampai saat ini belum banyak dimanfaatkan. Peminat dan penjual buah pisang biasanya hanya memanfaatkan buahnya saja, sementara itu kulitnya dibuang dan menjadi sampah organik (Salimi \& Payu, 2019). Sampah organik yang semakin meningkat dan tidak optimal pengolahannya, menjadi suatu permasalahan di lingkungan. Saat ini, pengolahan sampah organik telah banyak dilakukan, salah satunya dengan memanfaatkan serangga agen biokonverter.

Lalat tentara hitam (Hermetia illucens) atau black soldier fly (BSF) merupakan salah satu serangga pengurai yang mampu mendekomposisi berbagai macam jenis sampah organik, di antaranya adalah kotoran hewan, sisa sayuran yang telah membusuk, sisa buah-buahan, residu limbah pabrik tahu, dan limbah organik lainnya yang sulit untuk dicerna seperti ampas kopi (James, 1935; Xiao et al., 2018, Meneguz et al., 2018; Nguyen et al., 2013; Kinasih et al., 2018; Permana et al., 2018). Kemampuan larva BSF mendekomposisi bahan organik juga dilaporkan lebih baik dibandingkan cacing tanah (Sastro, 2016). Biokonversi yang dilakukan oleh BSF juga dilaporkan dapat mengurangi limbah organik mencapai 56\% (Suciati \& Faruq, 2017). Selain itu, larva BSF tidak berperan sebagai vektor penyakit dan relatif aman bagi kesehatan manusia (Wardhana, 2016).

Larva BSF juga dilaporkan dapat dijadikan sebagai pakan bagi hewan ternak daratan maupun perairan. Kandungan nutrisinya yang tinggi dimanfaatkan peternak sebagai sumber bahan pakan hewan ternak. Larva BSF memiliki kandungan protein sebesar 40-50\%, termasuk kandungan asam amino esensial yang dapat dimanfaatkan sebagai pengganti tepung ikan untuk ransum ternak (Mawaddah dkk., 2018). Kandungan asam amino paling banyak pada larva BSF di antaranya adalah methionin dan lisin masing-masing sebesar 9,05 dan $22,3 \mathrm{~g} / \mathrm{kg}$ (berat kering) (Veldkamp et al., 2012). Kandungan nutrisi yang ada dalam tubuh serangga salah satunya ditentukan oleh media tumbuh yang dipakai pada saat proses budidaya (Jintasataporn, 2012).

Berbagai macam manfaat dan kegunaan BSF, membuat banyak peneliti melakukan riset mengenai serangga ini. Namun demikian, penelitian mengenai informasi aspek biologis dalam bidang dinamika populasi masih perlu banyak dikaji untuk memahami sifat hidup serangga ini. Konstruksi tabel hidup serangga merupakan salah satu alat yang penting dalam memahami dinamika populasi serangga (Kakde et al., 2014). Pengetahuan mengenai tabel hidup dapat memberikan informasi mengenai waktu kecenderungan BSF tumbuh dan berkembang (metamorfosis). Informasi mengenai fase pra oviposisi, perilaku perkawinan, oviposisi, dan jumlah telur BSF juga dapat diketahui melalui analisis tabel hidup. Analisis tabel hidup yang banyak digunakan yaitu dengan menggunakan metode, age-stage two-sex life table (Chi \& Liu 1985; Chi, 1988). Analisis two-sex life table memberikan keuntungan informasi parameter populasi yang lebih realistis, memperhitungkan variabilitas antar individu di setiap stadia secara lengkap, dan dapat mengetahui kerentanan yang berbeda pada setiap tahapan hidup (Chi, 1998). Informasi terkait mortalitas, fekunditas, rasio kelamin, kecepatan pertumbuhan populasi dalam satu generasi, potensi reproduksi, dan periode hidup $H$. illucens perlu diketahui untuk pemahaman perbanyakan serangga ini secara massal. Tujuan dari penelitian ini adalah untuk mengetahui potensi reproduksi BSF yang ditumbuhkan pada media kulit pisang berdasarkan analisis tabel hidup.

\section{BAHAN DAN METODE}

\section{Perbanyakan dan Pemeliharaan H. Illucens}

Telur BSF diperoleh dari populasi yang dipelihara di Laboratorium Toksikologi Lingkungan, Sekolah Ilmu dan Teknologi Hayati, Institut Teknologi Bandung. Kondisi fisik penelitian adalah: temperatur $18-28^{\circ} \mathrm{C}$, kelembapan relative $55-90 \%$, dan periode waktu pencahayaan 12:12 jam terang:gelap.

Serangga dewasa diberi pakan larutan madu sebanyak 5\%. Selanjutnya, larutan madu dioleskan pada kapas, kemudian digantung di dalam kandang berukuran $50 \times 50 \times 50 \mathrm{~cm}$ dan dilapisi kain tile berwarna putih. Media peletakan telur (ovitrap) menggunakan tumpukan stik es krim. Larva dipelihara dan diberi substrat pakan ayam komersil.

\section{Studi Tabel Hidup $H$. Illucens}

Sebanyak 100 butir telur dipisahkan dan ditumbuhkan di wadah plastik kecil berukuran diameter $5 \mathrm{~cm}$ dengan tinggi $3 \mathrm{~cm}$ secara individual. Pada stadia larva, larva diberi pakan setiap tiga hari sekali dengan perlakuan substrat kulit pisang dan pakan ayam sebagai kontrol. Pakan yang diberikan 
pada larva sebanyak $100 \mathrm{mg} /$ larva/hari. Periode hidup larva, prapupa, dan pupa dicatat untuk mendapatkan data periode hidup masing-masing stadia BSF. Pada tahapan dewasa, serangga jantan dan betina yang terbentuk dihitung dan di tempatkan dalam wadah toples plastik dengan ukuran diameter $15 \mathrm{~cm}$ dan tinggi $25 \mathrm{~cm}$. Tutup toples dilubangi dan ditutupi oleh kain tile sebagai ventilasi, dengan masing-masing toples berisi ovitrap. Ovitrap dilapisi dengan lakban hitam untuk memudahkan perhitungan jumlah telur. Atraktan yang dipakai untuk menarik betina berviposisi menggunakan substrat masing-masing perlakuan (kulit pisang, dan pakan ayam sebagai kontrol. Periode pra oviposisi, oviposisi dan pasca oviposisi di hitung hingga serangga dewasa mati.

\section{Analisis Data}

Data tabel hidup populasi BSF dianalisis menggunakan pendekatan tahap usia, teknik tabel hidup dua jenis kelamin (age-stage two-sex life table) (Chi \& Liu, 1985; Chi 1988). Rata-rata, varians, dan standard error dihitung dengan menggunakan metode bootstrap (Huang \& Chi, 2012; Efron \& Tibshirani, 1993). Analisis Data dilakukan menggunakan TWOSEX-MsChart (Chi, 2015), ditulis dalam Visual BASIC untuk sistem operasi Windows, dan tersedia di http://140.120.197.173/Ecology/. Pengamatan tabel kehidupan BSF dilakukan berdasarkan tabel kehidupan horizontal (tahapan usia). Observasi dilakukan berdasarkan penelitian yang dilakukan oleh Samayoa et al. (2016) (Tabel 1).

Tabel 1. Definisi dan rumus yang digunakan untuk menghitung parameter populasi $H$. illucens .

\begin{tabular}{|c|c|c|}
\hline Parameter & Definisi & Rumus \\
\hline$x$ & Umur & \\
\hline$j$ & Stadia & \\
\hline$S_{x j}$ & $\begin{array}{l}\text { Tingkat keberhasilan spesifik umur, yaitu kemungkinan } \\
\text { individu dapat bertahan pada umur } x \text { dan stadia } j\end{array}$ & \\
\hline$l_{x}$ & Tingkat keberhasilan spesifik umur (versi sederhana dari $s_{x j}$ ) & $l_{x}=\sum_{j=1}^{\beta} s_{x j}$ \\
\hline$m_{x}$ & $\begin{array}{l}\text { Fekunditas spesifik umur, yaitu rata-rata jumlah telur yang } \\
\text { dihasilkan per individu betina pada hari ke- } X\end{array}$ & $\frac{m_{x}=\sum_{j=1}^{\beta} s_{x j} f_{x j}}{l_{x}=\sum_{j=1}^{\beta} s_{x j}}$ \\
\hline$r$ & Laju kenaikan intrinsik populasi & $\sum_{x=0}^{\infty} e^{-r(x+1)} l_{x} m_{x}=1$ \\
\hline$\lambda$ & Laju terbatas, yaitu kenaikan individu persatuan waktu & $\lambda=e^{r}$ \\
\hline Ro & $\begin{array}{l}\text { Laju reproduksi bersih, yaitu rata-rata jumlah keturunan yang } \\
\text { dihasilkan individu sepanjang hidupnya }\end{array}$ & $R_{0}=\sum_{x=0}^{\infty} l_{x} m_{x}$ \\
\hline$T$ & $\begin{array}{l}\text { Rata-rata waktu generasi, yaitu durasi waktu yang dibutuhkan } \\
\text { populasi untuk meningkat sebanyak Ro kali lipat dari } \\
\text { ukurannya, saat populasi mencapai distribusi tahap usia yang } \\
\text { stabil }\end{array}$ & $T=\frac{\ln R_{0}}{r}$ \\
\hline
\end{tabular}

\section{HASIL DAN PEMBAHASAN}

\section{Tabel Hidup H. illucens}

Informasi yang dihasilkan dari analisis tabel kehidupan berisi data dasar mengenai informasi biologis di bidang dinamika populasi makhluk hidup. Rata-rata dan standar error parameter tabel hidup BSF pada setiap tahap kehidupan yang dipelihara secara individual disajikan pada Tabel 2. Dari 100 telur yang ditumbuhkan, semuanya menetas dalam waktu 3 hari. Waktu perkembangan larva berbeda untuk setiap perlakuan. Lama waktu 
perkembangan larva tercepat berturut-turut adalah pakan ayam $(10,70 \pm 0,11$ hari $)$ dan kulit pisang $(16,22 \pm 0,13$ hari). Lama perkembangan larva yang diberi pakan kulit pisang memiliki waktu yang hampir sama dengan larva yang diberi pakan sisa sayur (16 hari) (Julita et al., 2018). Secara umum durasi perkembangan larva dari kedua perlakuan ini masih lebih cepat dari laporan penelitian sebelumnya yaitu dengan pakan dedak gandum, fermentasi jerami jagung, dan campuran pakan ayam dengan dedak gandum. (Gao et al., 2019; Samayoa et al., 2016). Larva serangga cenderung mengonsumsi makanan yang relatif seimbang dan mencukupi untuk pertumbuhan dan perkembangannya, sehingga menghasilkan serangga dewasa yang kompetitif secara reproduktif (Julita et al., 2018). Larva BSF dilaporkan tumbuh lebih cepat pada substrat dengan kandungan nutrisi seimbang dibandingkan dengan yang tumbuh pada media substrat yang hanya kaya protein dan kaya serat (Tschirner \& Simon, 2015). Pemberian pakan yang hanya kaya serat pada substrat bahkan menyebabkan larva berhenti berkembang (Tschirner \& Simon, 2015). Dengan demikian, kualitas makanan/substrat berperan penting dalam perkembangan serangga dewasa (Gobbi et al., 2013).

Durasi stadia prapupa masing-masing perlakuan yaitu 4,79 $\pm 0,24$ (kulit pisang) dan 4,83 \pm 0,16 hari (pakan ayam) (Tabel 2). Jumlah serangga dewasa yang berhasil muncul pada perlakuan kulit pisang dan pakan ayam masing-masing adalah 71 dan 78. Sebagai informasi tambahan, rasio kelamin serangga dewasa yang diamati dari masing-masing perlakuan adalah dan 30:41, dengan 13 serangga betina tidak menghasilkan telur (kulit pisang) dan 29:49, dengan 6 serangga betina tidak menghasilkan telur (pakan ayam).

Tabel 2. Waktu perkembangan, durasi umur serangga dewasa, fekunditas, periode praoviposisi serangga dewasa (APOP), total periode praoviposisi (TPOP), dan waktu oviposisi lalat tentara hitam (Black Soldier Fly) Hermetia illucens yang ditumbuhkan secara individual pada substrat kulit pisang dan pakan ayam.

\begin{tabular}{llcc}
\hline Parameter & Stadia & Kulit pisang & Pakan ayam \\
\hline \multirow{3}{*}{ Waktu perkembangan (hari) } & Telur & $3 \pm 0$ & $3 \pm 0$ \\
\cline { 2 - 4 } & Larva & $16,22 \pm 0,13$ & $10,70 \pm 0,11$ \\
\cline { 2 - 4 } & Pra pupa & $4,79 \pm 0,24$ & $4,83 \pm 0,16$ \\
\cline { 2 - 4 } & Pupa & $22,50 \pm 0,32$ & $21,88 \pm 0,40$ \\
\hline \multirow{2}{*}{ Total panjang umur serangga (hari) } & Jantan & $57,78 \pm 0,76$ & $52,91 \pm 0,50$ \\
\cline { 2 - 4 } & betina & $58,06 \pm 0,73$ & $51,13 \pm 0,78$ \\
\hline Pra oviposisi serangga dewasa (hari) & APOP & $4,17 \pm 0,25$ & $4,86 \pm 0,26$ \\
\cline { 2 - 4 } & TPOP & $50,35 \pm 0,71$ & $44,48 \pm 0,86$ \\
\hline Fekunditas (telur/betina) & Betina & $175,32 \pm 34,03$ & $408,37 \pm 49,37$ \\
\hline Waktu oviposisi (hari) & Betina & $1,00 \pm 0$ & $1,52 \pm 0,13$ \\
\hline
\end{tabular}

Keterangan: Nilai rata-rata dan standard error dikalkulasikan berdasarkan metode bootstrap dengan perangkat lunak $T_{\text {wo-seX- }}$

MSChart.

Rata-rata panjang umur stadia dewasa BSF pada perlakuan kulit pisang dan pakan ayam masingmasing yaitu selama $11,2 \pm 0,52$ dan $11,97 \pm 0,48$ hari. Sebagai informasi tambahan, panjang umur maksimal serangga dewasa pada penelitian ini masih lebih lama 1-4 hari dibandingkan dengan laporan penelitian Samayoa et al. (2016). Panjang umur serangga dapat ditentukan oleh mekanisme penuaan (aging) (Loof, 2011). Penuaan biologis (senescence) berlaku untuk proses yang diprogram secara genetik dan epigenetik yang ditimbulkan sebagian oleh kondisi tercekam atau stress yang memengaruhi sel (penuaan seluler dan kematian sel terprogram) dari suatu organisme dan organisme secara keseluruhan (penuaan organisme) setelah kematangan seksual (Loof, 2011; Eisenberg et al., 2009).

Rata-rata periode waktu praoviposisi BSF betina/adult praoviposition period (APOP) pada perlakuan kulit pisang tercatat selama 4,17 hari dengan total periode waktu praoviposisi BSF betina/total preoviposition period (TPOP) selama 50,35 hari. Sementara itu, BSF betina pada perlakuan pakan ayam memiliki APOP selama 4,86 hari dan TPOP selama 44,48 hari. TPOP merupakan periode waktu dari telur yang menetas ke individu betina yang bereproduksi. TPOP dapat dideskripsikan 
secara lebih tepat sebagai "praoviposisi" karena mempertimbangkan variasi dari tahap pra dewasa (Zied et al., 2003). Sementara itu, APOP merupakan periode waktu munculnya serangga betina dan melakukan oviposisi untuk pertama kalinya. APOP dapat dideksripsikan sebagai praoviposisi yang tidak mempertimbangkan variasi stadia pra dewasa. Durasi waktu TPOP yang panjang memungkinkan terjadinya kerugian bagi produksi massal BSF dan dapat mengurangi keefektifan peran serangga tersebut sebagai pengurai, terutama karena sisa tahapan hidupnya adalah tahapan tanpa perlu adanya asupan nutrisi (non-feeding) (Samayoa et al., 2016). Tomberlin \& Sheppard (2002), melaporkan bahwa BSF betina mampu bertahan dua hari setelah kawin dan mati dalam beberapa jam. Pada penelitian ini, BSF jantan terlihat dapat bertahan jauh lebih lama dibandingkan dengan betina.

Fekunditas serangga betina paling tinggi dihasilkan dari perlakuan pemberian pakan ayam $(408,37 \pm 49,37$ butir, dengan perlakuan kulit pisang memiliki nilai rata-rata telur yang dihasilkan relatif sedikit, yaitu sebanyak 175,32 \pm 34,03 butir. Walaupun jumlah telur yang dihasilkan pada perlakuan kulit pisang lebih rendah, nilai fekunditas ini masih lebih tinggi jika dibandingkan dengan penelitian Julita et al. (2018), dengan rata-rata fekunditas sebesar $131 \pm 18,7$ dan $138 \pm 19,9$ butir masing-masing pada perlakuan pemberian sisa sayuran dan buah-buahan. Hal ini diduga kualitas nutrisi yang ada di dalam kulit pisang lebih baik dalam mendukung produksi BSF. Hasil penelitian Macavei et al. (2020), menunjukkan bahwa parameter produksi BSF dipengaruhi terutama oleh nutrisi dibandingkan dengan faktor cahaya, meskipun cahaya memainkan peran sekunder yang penting.

\section{Analisis Parameter Populasi BSF}

Hasil analisis parameter populasi BSF dengan parameter nilai reproduksi bersih $(R o)$, tingkat intrinsik kenaikan $(r)$, tingkat kenaikan terbatas $(\lambda)$, dan rata-rata waktu generasi ( $T$ ) disajikan pada Tabel 3. Nilai reproduksi bersih ( $R o)$ BSF pada perlakuan kulit pisang dan pakan ayam berturutturut yaitu sebesar dan $52,57 \pm 12,88$ dan $118,40 \pm$ 23,28 butir. Walaupun nilai reproduksi bersih pada perlakuan kulit pisang cukup rendah, nilai ini masih lebih tinggi dibandingkan dengan yang dilaporkan Firdaus (2019), yaitu sebesar 50,01 \pm 12.24 pada perlakuan pemberian ampas kelapa. Nilai $R o>1$, mengindikasikan bahwa populasi dapat bertahan pada generasi selanjutnya (de-Camino-Beck \& Lewis, 2008). Rata-rata keberhasilan reproduksi seumur hidup $(R o)$ sangat erat kaitannya dengan $r$, serta merangkum kinerja kelangsungan hidup dan kesuburan individu dalam suatu kelompok seiring bertambahnya usia (Schindler et al., 2012). Hasil analisis menunjukkan bahwa nilai $r$ pada perlakuan pakan ayam sebesar $0,106 \pm 0,005$ dan pada kulit pisang terlihat lebih rendah, yaitu sebesar 0,073 \pm 0,005 . Populasi BSF yang ditumbuhkan pada substrat kulit pisang memiliki nilai $\lambda$ yang lebih rendah, yaitu sebesar $1,080 \pm 0,005$. Walaupun demikian, populasi BSF yang ditumbuhkan pada substrat kulit pisang menunjukkan adanya laju peningkatan populasi $(r>0)$ dan perubahan ukuran populasi yang semakin tinggi $(\lambda>1)$ (Schindler et al., 2012; Stratton, 2010). Tingkat intrinsik kenaikan ( $r$ ), tingkat kenaikan terbatas $(\lambda)$, dan tingkat reproduksi bersih $(R o)$ mencerminkan efek konklusif dari perkembangan, kelangsungan hidup, dan reproduksi pada kesesuaian populasi (fitness) (Akköprü et al., 2015). Terdapat hubungan yang erat diantara nilai $r$ dan $\lambda$, dengan $\lambda$ merupakan kontribusi individu terhadap total ukuran populasi, sedangkan $r$ merupakan kontribusi individu terhadap laju perubahan ukuran populasi (Stratton, 2010). Dalam populasi usia terstruktur (age-structured populations) dengan generasi yang tumpang tindih, laju pertumbuhan populasi $(r$ ) biasanya ditentukan oleh fungsi kelahiran $\left(l_{x} m_{x}\right)$ yang merupakan hasil dari tingkat kelangsungan hidup spesifik usia (lx) dan tingkat kesuburan $\left(m_{x}\right)$ (Schindler et al., 2012). Sebagai tambahan, tingkat pertumbuhan $r$ menggambarkan kinerja kelangsungan hidup dan kesuburan semua individu dan kelompok, dalam kaitannya dengan tingkat pertumbuhan populasi jangka panjang (Schindler et al., 2012).

Rata-rata waktu generasi (T) BSF yang ditumbuhkan pada pakan ayam yaitu selama 44,75 \pm 1,12 hari, sementara itu pada substrat kulit pisang sebesar 50,85 $\pm 0,69$ hari. Waktu generasi merupakan durasi waktu yang dibutuhkan untuk menyelesaikan satu generasi (Li, 1995). Serangga dengan waktu generasi yang pendek memiliki tingkat peningkatan populasi yang lebih tinggi dibandingkan dengan serangga yang secara komparatif memiliki waktu generasi yang lebih lama (Li, 1995). Suhu dan kualitas makanan merupakan dua faktor kunci yang dapat memengaruhi waktu generasi (Li, 1995). Radford (1967), mendemonstrasikan bahwa ketersediaan makanan memengaruhi rata-rata pertumbuhan relatif. 
Tabel 3. Nilai reproduktif bersih $(R o)$, tingkat intrinsik kenaikan $(r)$, tingkat kenaikan terbatas $(\lambda)$, dan waktu generasi ( $T$ ) BSF $H$. illucens yang ditumbuhkan pada substrat pakan ayam, kulit pisang.

\begin{tabular}{lll}
\hline Parameter & Kulit pisang & Pakan ayam \\
\hline$R o$ & $52,57 \pm 12,88$ & $118,40 \pm 23,28$ \\
\hline$r$ & $0,073 \pm 0,005$ & $0,106 \pm 0,005$ \\
\hline$\lambda$ & $1,080 \pm 0,005$ & $1,112 \pm 0,006$ \\
\hline$T$ & $50,85 \pm 0,69$ & $44,75 \pm 1,12$ \\
\hline
\end{tabular}

Keterangan: Nilai rata-rata dan standard error dikalkulasikan berdasarkan metode bootstrap pada perangkat lunak Two-sex-MSChart.

Tingkat Keberhasilan Hidup Spesifik Umur BSF

Tingkat keberhasilan hidup spesifik umur $\left(s_{x}\right)$ dari lalat tentara hitam yang ditumbuhkan secara individu pada substrat yang berbeda mengindikasikan kemungkinan individu yang baru lahir dapat bertahan pada umur $x$ dan berkembang pada tahapan $j$. Variasi individu ini diamati sebagai tumpang tindih antara tahap dan dalam kurva kelangsungan hidup (Gambar 1). Jumlah individu yang bertahan pada tahapan larva bervariasi dengan perlakuan kulit pisang dan pakan ayam masingmasing sebesar $100 \%$ dan 96\%. Tingkat kelangsungan hidup stadia larva masih tergolong cukup tinggi ( $>90 \%)$. Durasi waktu pertumbuhan telur hingga serangga dewasa mati, pada perlakuan kulit pisang dan pakan ayam masing-masing sebesar $57,90 \pm 0,54$ dan $52,26 \pm 0,44$ hari.
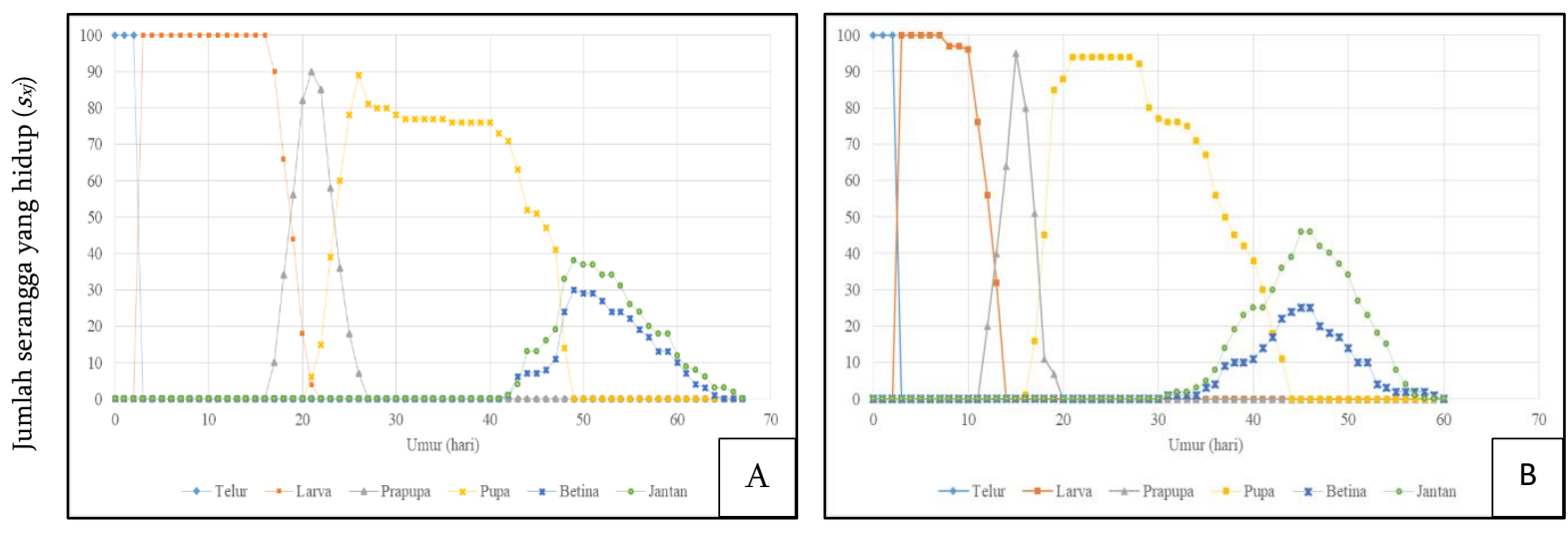

Gambar 1. Tingkat keberhasilan hidup spesifik umur H. illucens (sx) pada substrat kulit pisang (A) dan pakan ayam (B).

\section{Harapan Hidup BSF}

Berdasarkan tingkat kelangsungan hidup tahap usia, kami menghitung harapan hidup untuk setiap interval tahap usia (Gambar 2) untuk prediksi kehidupan masa depan populasi. Harapan hidup $\left(e_{x j}\right)$ adalah waktu yang diharapkan individu untuk hidup pada usia $x$ dan tahap $j$. Dari Gambar 2 terlihat bahwa usia harapan hidup BSF pada tahapan telur, larva, dan dewasa lebih tinggi pada pakan ayam dibandingkan kulit pisang. Hal ini diduga karena kandungan nutrisi yang ada didalam pakan ayam lebih baik dibandingkan dengan kulit pisang. Harapan hidup pada BSF dapat dipengaruhi oleh jenis substrat/pakan yang diberikan serta suhu (Samayoa, 2016). 

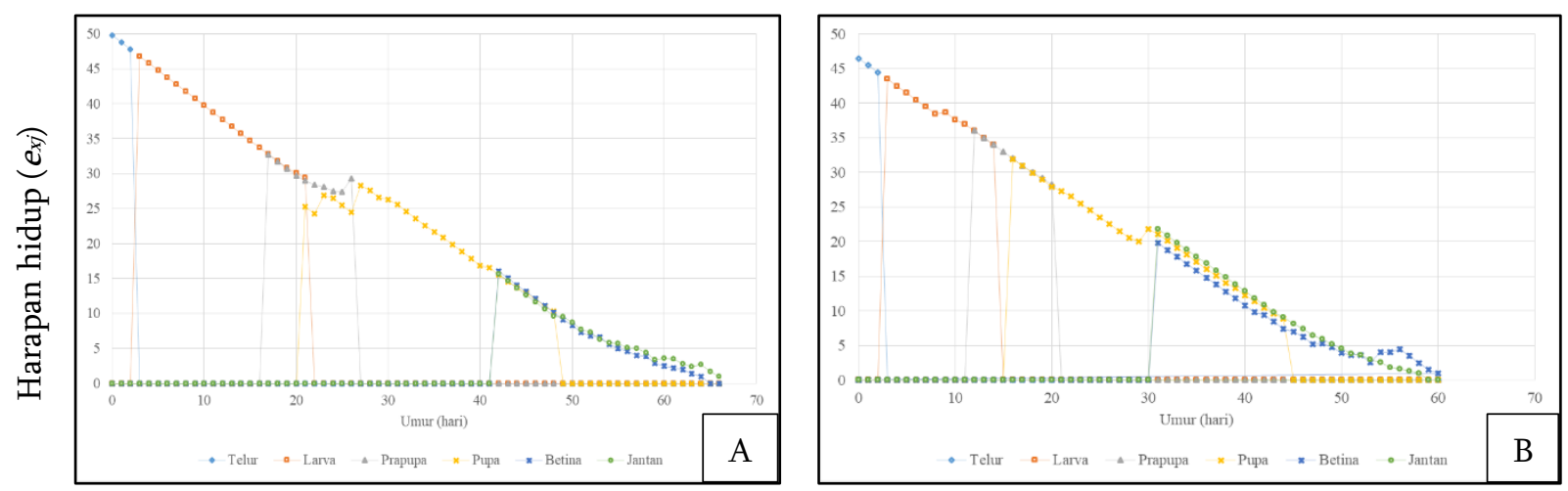

Gambar 2. Harapan hidup H. illucens setiap stadia umur (exj) (umur $\mathrm{x}$ dan tahapan j) individu BSF yang ditumbuhkan pada substrat kulit pisang (A) dan pakan ayam (B).

Tingkat keberhasilan hidup spesifik umur $\left(l_{x}\right)$, fekunditas spesifik umur $\left(m_{x}\right)$, dan nilai reproduktif $\left(v_{x}\right)$ BSF

Dengan mengabaikan perbedaan stadia, tingkat kelangsungan hidup spesifik umur tunggal (lx) memberikan probabilitas bahwa individu baru lahir akan bertahan hidup sampai usia $x$ (Gambar 3). Tingkat kelangsungan hidup spesifik umur $\left(l_{x}\right)$ dan fekunditas spesifik umur $\left(m_{x}\right)$ dihitung dengan memasukkan semua individu dari kedua jenis kelamin. Kurva $l_{x}$ menggambarkan perubahan tingkat kelangsungan hidup populasi kohort dengan usia. Kurva $m_{x}$ pada perlakuan pakan ayam mulai muncul pada hari ke-35 dengan nilai $m_{x}$ sebesar 5,72 dan puncaknya terjadi pada hari ke-52 sebesar 33,35 telur. Kurva fekunditas pada populasi BSF yang ditumbuhkan pada kulit pisang memiliki puncak nilai sebesar 20,3 telur pada hari ke-51(Gambar 3).
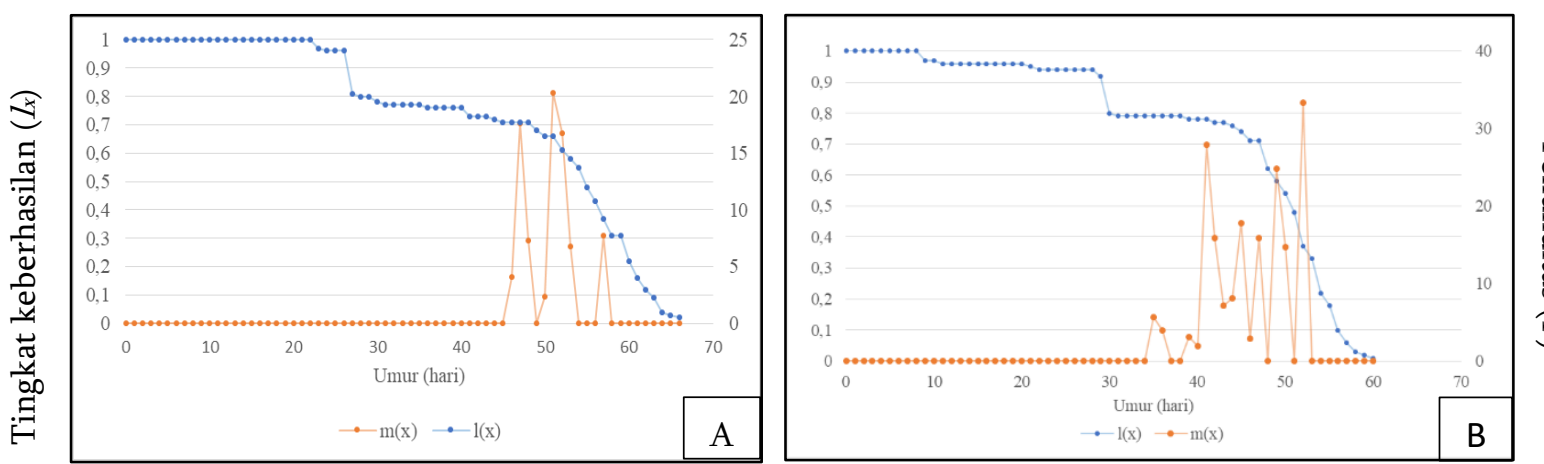

Gambar 3. Tingkat keberhasilan hidup spesifik umur $\left(\mathrm{l}_{\mathrm{x}}\right)$ dan fekunditas stadia umur $\left(\mathrm{m}_{\mathrm{x}}\right) \mathrm{H}$. illucens yang ditumbuhkan pada substrat pakan ayam (A) dan kulit pisang (B).
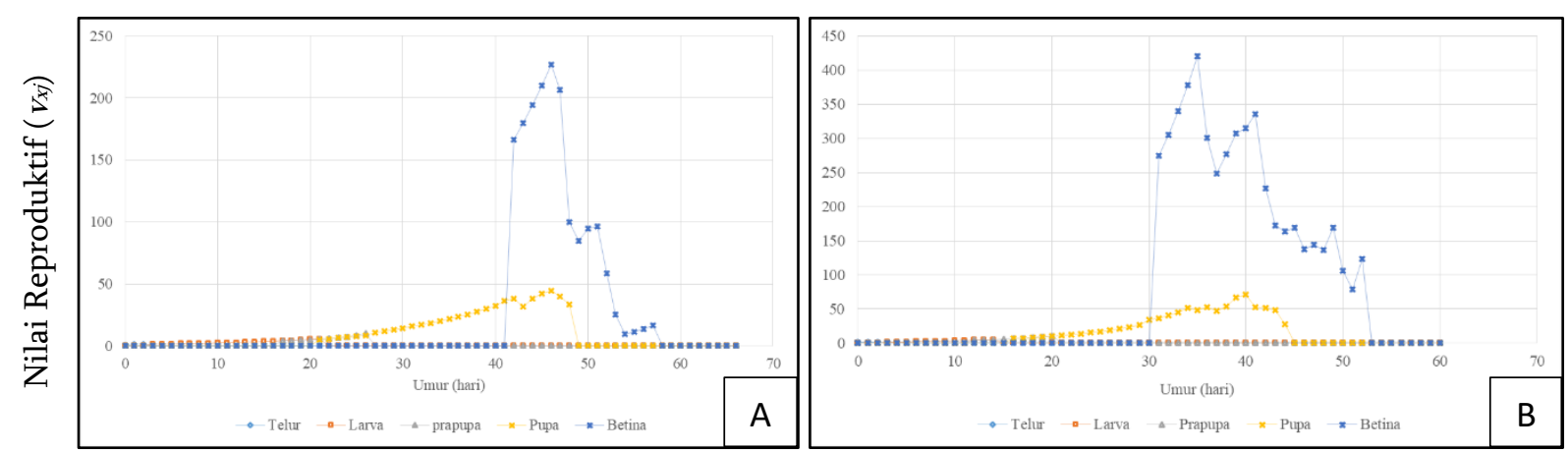

Gambar 4. Nilai reproduktif (vx) H. illucens yang ditumbuhkan pada substrat kulit pisang (A) dan pakan ayam (B). 
Kontribusi individu untuk populasi masa depan disebut sebagai nilai reproduktif (Julita et al., 2018). Nilai reproduksi meningkat dari tahap telur ke dewasa dan meningkat secara signifikan pada saat munculnya betina dewasa (Gambar 4). Tidak ada kurva reproduktif pada serangga jantan yang digambarkan, hal ini disebabkan karena kontribusi serangga jantan terhadap populasi yang akan mendatang tidak dapat ditentukan (Fisher, 1930).

\section{SIMPULAN DAN SARAN}

Berdasarkan analisis tabel hidup yang telah dilakukan, dapat disimpulkan bahwa $H$. illucens yang diberi pakan ayam memiliki parameter reproduksi yang lebih baik daripada limbah kulit pisang. Walaupun demikian, penelitian ini menunjukkan bahwa BSF dapat digunakan sebagai biokonverter limbah kulit pisang. Sebagai tambahan, perlu dilakukan pencacahan dan fermentasi kulit pisang sehingga dapat dengan mudah dicerna oleh larva $H$. illucens. Analisis proksimat kulit pisang juga diperlukan untuk mengetahui hubungan antara kandungan nutrisi substrat pemeliharaan dengan nilai reproduksi.

\section{UCAPAN TERIMA KASIH}

Penulis mengucapkan terimakasih kepada seluruh pihak yang telah berkontribusi dalam penelitian ini. Penulis juga mengucapkan terima kasih kepada Pak Suyitno yang telah menyediakan kami Hermetia illucens.

\section{DAFTAR PUSTAKA}

Akköprü, EP, R Atlihan, H Okut, and H Chi. 2015. Demographic assessment of plant cultivar resistance to insect pests: a case study of the dusky-veined walnut aphid (Hemiptera: Callaphididae) on five walnut cultivars. Journal of Economic Entomology. 108(2): 378-387.

Chi, H, and H Liu. 1985. Two new methods for the study of insect population ecology. Academia Sinica. 24(2): 225-240.

Chi, H. 1988. Life table analysis incorporating both sexes and variable development rates among individuals. Journal of Environmental Entomology. 17(1): 26-34.

Chi, H. 2015. TWOSEX-MSChart: A computer program for the age-stage, two-sex life table analysis. National Chung Hsing University, Taichung, Taiwan.

Eisenberg, T, H Knauer, A Schauer, S Büttner, C Ruckenstuhl, Carmona-Gutierrez, J Ring, S Schroeder, C Magnes, L Antonacci, H Fussi, L Deszcz, R Hartl, E Schraml, A Criollo, E Megalou, D Weiskopf, P Laun, G Heeren, M Breitenbach, B Grubeck-Loebenstein, E Herker, B Fahrenkrog, KU Fröhlich, F Sinner, N Tavernarakis, E Minois, G Kroemer, and F Madea. 2009. Induction of autophaghy by spermidine promotes longevity. Nature Cell Biology. 11: 1305-1314.

Efron, B, and RJ Tibshirani. 1993. An Introduction to the Bootstrap. Chapman \& Hall. Newyork. USA.

De-Camino-Beck, T, and MA Lewis. 2008. On net reproductive rate and the timing of reproductive output. The American Naturalist. 172(1): 128-139.

Firdaus, F. 2019. Efisiensi Konversi dan Tabel Hidup Lalat Tentara Hitam Hermetia illucens L. (Diptera: Stratiomyidae) yang Dipelihara pada Limbah Ampas Kelapa, Tesis Program Master, Institut Teknologi Bandung.

Fisher, RA. 1930. The Genetical Theory of Natural Selection. Clarendon Press. 272 pp.

Gao, Z, W Wang, X Lu, F Zhu, W Liu, X Wang, and C Lei. 2019. Bioconversion performance and life table of black soldier fly (Hermetia illucens) on fermented maize straw. Journal of Cleaner Production. 230: 974-980.

Gobbi, P, A Martinez-Sanchez, and S Rojo. 2013. The effect of larval diet on adult life-history traits of the black soldier fly, Hermetia illucens (Diptera: Stratiomyidae). European Journal of Entomology. 110(3): 461-468.

Huang, YB, and H Chi. 2012. Life tables of Bactrocera cucurbitae (Diptera: Tephritidae): with an invalidation of the Jackknife Technique. Journal of Applied Entomology. 137(5): 327-339.

James, MT. 1935. The genus Hermetia in the United States (Diptera: Stratiomyidae). Bull. Brooklyn Entomology Society. 30: 165-170.

Jintasataporn, O. 2012. Production performance of broiler chickens fed with silkworm pupa (Bombyx mori). Journal of Agricultural Science and Technology. 2: 505-510.

Julita, U, LL Fitri, RE Putra, and AD Permana. 2018. Survival and Reproductive Value of Hermetia illucens (Diptera: Stratiomyidae) on 
Vegetable and Fruits Waste Rearing Substrate. International Conference on Mathematics and Natural Sciences (ICMNS).

Kakde, AM, KG Patel, and S Tayade. 2014. Role of life table in insect pest management. A Review. IOSR Journal of Agriculture and Veterinary Science. 7(1): 40-43.

Kinasih, I, RE Putra, AD Permana, FF Gusmara, MY Nurhadi, and RA Anitasari. 2018. Growth performance of black soldier fly larvae (Hermetia illucens) fed on some plant based organic wastes. HAYATI Journal of Biosciences. 25(2): 79-84.

Li, T. 1995. Shortest generation time. Book of Insect Records. University of Florida. Available online at

http://entnemdept.ufl.edu/walker/ufbir/chapt ers/chapter_06.shtml. (diakses 26 Mei 2021).

Loof, AD. 2011. Longevity and aging in insects: is reproduction costly; cheap; beneficial or irrelevant? a critical evaluation of the "Tradeoff” concept. Journal of Insect Physiology. 57(1): 1-11.

Macavei, LL, G Benassi, V Stoian, and L Maistrello. 2020. Optimization of Hermetia illucens (L.) egg laying under different nutrition and light conditions. PLoS ONE. 15(4): e0232144.

Mawaddah, S, W Hermana, dan Nahrowi. 2018. Pengaruh pemberian tepung deffated larva BSF (Hermetia illucens) terhadap perfoma produksi puyuh petelur (Coturnix coturnix japonica). Jurnal Ilmu Nutrisi dan Teknologi Pakan. 16(3): 47-51.

Meneguz, M, A Schiavone, F Gai, A Dama, C Lussiana, M Renna, and L Gasco. 2018. Effect of rearing substrate on growth performance, waste reduction efficiency and chemical composition of black soldier fly (Hermetia illucens) larvae. Journal of the Science of Food and Agriculture. 98(15): 5776-5784.

Nguyen, TTX, JK Tomberlin, and S Vanlaerhoven. 2015. Ability of black soldier fly (Diptera: Stratiomyidae) larvae to recycle food waste. Physiological Ecology. 44(2): 406-410.

Permana, AD, JN Esther, and RE Putra. 2018. Growth of black soldier fly (Hermetia illucens) larvae fed on spent coffee ground. IOP Conf. Series: Earth and Environmental Science.

Radford, PJ. 1967. Growth Analysis Formulae Their Use and Abuse. Crop Science. 7(3): 171175.
Salimi, YK, dan CS Payu. 2019. Pemberdayaan masyarakat dalam peningkatan nilai tambah pengolahan limbah kulit pisang (Musa paradisiaca) menjadi tepung untuk meningkatkan pendapatan masyarakat. Jurnal Pengabdian Kepada Masyarakat. 25(1): 42-26.

Samayoa, AC, W Chen, and S Hwang. 2016. Survival and development of Hermetia illucens (Diptera: Stratomyidae): A biodegradation agent of organic waste. Journal of Economic Entomology. 109(6): 2580-2585.

Sastro, Y. 2016. Teknologi pengomposan organik kota menggunakan black soldier fly. Balai Pengkajian Teknologi Pertanian Jakarta. Available online at: http://jakarta.litbang.pertanian.go.id/ind/bros ur/WT\%20brosur\%20bsf.pdf (diakses 10 September 2019).

Schindler, S, S Tuljapurkar, JM Gaillard, and T Coulson. 2012. Linking the population growth rate and the age-at-death distribution. Theoretical Population Biology. 82(4): 244252.

Stratton, D. 2010. Case studies in ecology and evolution. Online Article. Available online at: http://www.uvm.edu/ dstratto/bcor102/readi ngs/01_Exponential_growth.pdf. (diakses 26 Mei 2021).

Suciati, R., dan H. Faruq. Efektivitas media pertumbuhan maggots Hermetia illucens (Lalat Tentara Hitam) sebagai solusi pemanfaatan sampah organik. Biosfer. 2(1): 813.

Tomberlin, JK, and DC Sheppard. 2002. Factors influencing mating and oviposition of black soldier flies (Diptera: Stratomyidae) in a colony. Journal of Entomological Science. 37(42): 345-352.

Tschirner, M, and A Simon. 2015. Influence of different growing substrates and processing on the nutrient composition of black soldier fly larvae destined for animal feed. Journal of Insects as Food and Feed. 1(4): 249-259.

Veldkamp, T, G van Duinkerken, A van Huis, CMM Lakemond, E Ottevanger, G Bosch, and MAJS. van Boekel. 2012. Insects as a sustainable feed ingredient in pig and poultry diets - a feasibility study. Wageningen UR Livestock Research. Report 638.

Wardhana, AH. 2016. Black soldier fly (Hermetia illucens) sebagai sumber protein alternatif 
untuk pakan ternak. Wartazoa. 26(2): 069078.

Xiao, X, L Mazza, Y Yu, M Cai, L Zheng, JK Tomberlin, J Yu, A van Huis, Z Yu, and S Fasulo. 2018. Efficient co-convervison process of chicken manure into protein feed and organic fertilizer by Hermetia illucens $\mathrm{L}$.
(Diptera: Stratiomyidae) larvae and functional bacteria. Journal of Environmental Management. 217: 668-676.

Zied, EMA, RM Gabre, and H Chi. 2003. Life table of the Australian Sheep Blow Fly Lucilia cuprina (Wiedmann) (Diptera: Calliphoridae). Egyptian Journal of Zoology. 41: 29-45. 